\title{
ASSOCIATION BETWEEN QUALITY OF SERVICE AND PATIENT SATISFACTION AT POASIA COMMUNITY HEALTH CENTER IN SOUTHEAST SULAWESI
}

\author{
Nurmaida Saana, Ascobat Gani, Rosarlian \\ Faculty of Public Health, Universitas Indonesia
}

\begin{abstract}
Background: Patient satisfaction is an indicator of the existing quality of health services. Patient satisfaction can affect patient loyalty of future health service. Recent data showed that outpatient visit to Poasia Community Health Center (Puskesmas) had decreased from $16.74 \%$ in 2012 to $11.38 \%$ in 2013 . This study aimed to examine the association between the quality of service and patient satisfaction at Poasia Puskesmas in Southeast Sulawesi.

Subjects and Method: A cross sectional study was conducted in the work area of Poasia Puskesmas, South East Sulawesi, from January to March 2014. A total sample of 97 outpatients was selected for this study at random. The independent variable was outpatient service quality. The dependent variable was patient satisfaction. The quality data were measured by ServQual instrument. Other data were collected using questionnaire and analyzed by chi square test.

Results: The empathy dimension of the quality of health service was positively associated with outpatient satisfaction $(\mathrm{OR}=0.29 ; 95 \% \mathrm{CI}=0.10$ to $0.85 ; \mathrm{p}=0.036)$. Other dimensions of quality were also associated but not statistically significant with patient satisfaction.

Conclusion: Quality of health service is associated with patient satisfaction. The empathy dimension of quality should be capitalized to improve the quality of outpatient service.
\end{abstract}

Keywords: quality, service, patient satisfaction

\section{Correspondence:}

Nurmaida Saana. Faculty of Public Health, Universitas Indonesia, Depok, West Java. Email: nurmaidasaanasaputri@gmail.com. Mobile: 081341815157.

The $6^{\text {th }}$ International Conference on Public Health Best Western Premier Hotel, Solo, Indonesia, October 23-24, 2019 | 277 https://doi.org/10.26911/the6thicph.04.39 